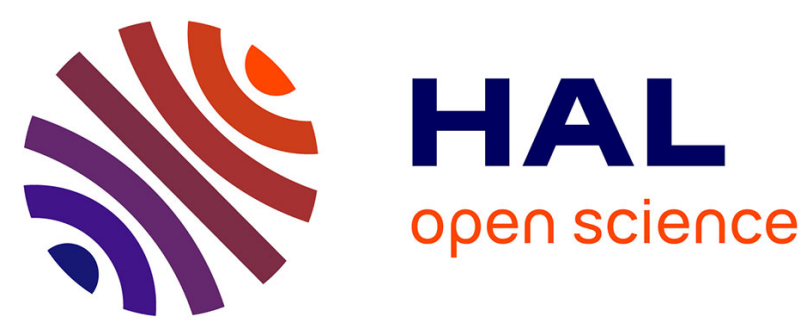

\title{
Retreat Pattern of Glaciers Controls the Occurrence of Turbidity Currents on High-Latitude Fjord Deltas (Eastern Baffin Island)
}

\author{
A Normandeau, Pierre Dietrich, J. Hughes Clarke, W van Wychen, P. \\ Lajeunesse, D. Burgess, J.-F Ghienne
}

\section{To cite this version:}

A Normandeau, Pierre Dietrich, J. Hughes Clarke, W van Wychen, P. Lajeunesse, et al.. Retreat Pattern of Glaciers Controls the Occurrence of Turbidity Currents on High-Latitude Fjord Deltas (Eastern Baffin Island). Journal of Geophysical Research: Earth Surface, 2019, 124 (6), pp.1559-1571. 10.1029/2018JF004970 . hal-02363959

\section{HAL Id: hal-02363959 https://hal.science/hal-02363959}

Submitted on 14 Nov 2019

HAL is a multi-disciplinary open access archive for the deposit and dissemination of scientific research documents, whether they are published or not. The documents may come from teaching and research institutions in France or abroad, or from public or private research centers.
L'archive ouverte pluridisciplinaire HAL, est destinée au dépôt et à la diffusion de documents scientifiques de niveau recherche, publiés ou non, émanant des établissements d'enseignement et de recherche français ou étrangers, des laboratoires publics ou privés. 


\section{JGR Earth Surface}

\section{RESEARCH ARTICLE 10.1029/2018JF004970 \\ Special Section: \\ The Arctic: An AGU Joint \\ Retreat Pattern of Glaciers Controls the Occurrence of Turbidity Currents on High-Latitude Fjord Deltas (Eastern Baffin Island)} Special Collection

Key Points:

- Glacial erosion is necessary to provide the sediment supply required for turbidity currents to be generated on delta fronts in eastern Baffin Island fjords

- Lakes formed during glacial retreat significantly alter sediment delivery, stopping turbidity currents

- Pattern of retreating glaciers dictates the nonlinear nearshore hydrodynamics of fjords

Supporting Information: - Data Set S1

Correspondence to: A. Normandeau,

alexandre.normandeau@canada.ca

Citation:

Normandeau, A., Dietrich, P., Hughes

Clarke, J., Van Wychen, W.

Lajeunesse, P., Burgess, D., \& Ghienne, J.-F. (2019). Retreat pattern of glaciers controls the occurrence of turbidity currents on high-latitude fjord deltas (eastern Baffin Island). Journal of Geophysical Research: Earth Surface, 124, 1559-1571. https://doi.org/ 10.1029/2018JF004970

Received 7 DEC 2018

Accepted 18 MAY 2019

Accepted article online 31 MAY 2019

Published online 25 JUN 2019

(C)2019. American Geophysical Union. All Rights Reserved.

\author{
A. Normandeau $^{1}$ (D) P. Dietrich ${ }^{2}$, J. Hughes Clarke ${ }^{3}$ (D) W. Van Wychen ${ }^{4}$ D, P. Lajeunesse ${ }^{5}$ (D), \\ D. Burgess ${ }^{6}$, and J.-F. Ghienne ${ }^{7}$
}

${ }^{1}$ Geological Survey of Canada (Atlantic), Natural Resources Canada, Dartmouth, Nova Scotia, Canada, ${ }^{2}$ Department of Geology, Auckland Park Kingsway Campus, University of Johannesburg, Johannesburg, South Africa, ${ }^{3}$ Center for Coastal and Ocean Mapping, University of New Hampshire, Durham, NH, USA, ${ }^{4}$ Defense Research and Development Canada, Department of National Defense, Ottawa, Ontario, Canada, ${ }^{5}$ Centre d'Études Nordiques and Département de Géographie, Université Laval, Québec, Québec, Canada, ${ }^{6}$ Geological Survey of Canada, Natural Resources Canada, Ottawa, Ontario, Canada, ${ }^{7}$ Institut de Physique du Globe de Strasbourg, UMR 7516 CNRS/Université de Strasbourg, Strasbourg, France

Abstract Glacier and ice sheet mass loss as a result of climate change is driving important coastal changes in Arctic fjords. Yet limited information exists for Arctic coasts regarding the influence of glacial erosion and ice mass loss on the occurrence and character of turbidity currents in fjords, which themselves affect delta dynamics. Here we show how glacial erosion and the production of meltwaters and sediments associated with the melting of retreating glaciers control the generation of turbidity currents in fjords of eastern Baffin Island (Canada). The subaqueous parts of 31 river mouths along eastern Baffin Island were mapped by high-resolution swath bathymetry in order to assess the presence or absence of sediment waves formed by turbidity currents on delta fronts. By extracting glaciological and hydrological watershed characteristics of these river mouths, we demonstrate that the presence and areal extent of glaciers are a key control for generating turbidity currents in fjords. However, lakes formed upstream during glacial retreat significantly alter the course of sediment routing to the deltas by forming temporary sinks, leading to the cessation of turbidity currents in the fjords. Due to the different deglaciation stages of watersheds in eastern Baffin Island, we put these results into a temporal framework of watershed deglaciation to demonstrate how the retreat pattern of glaciers, through the formation and filling of proglacial lakes, affects the turbidity current activity of deltas.

\section{Introduction}

High-latitude coasts are particularly sensitive to a warming climate, which promotes ice mass loss (Gardner et al., 2011; Zwally et al., 2011), longer open sea ice seasons (Overeem et al., 2011; Serreze et al., 2007), and, in some regions, a relative sea level rise (e.g., Ford et al., 2017). These environmental changes in turn drastically modify Arctic coastlines, either by increasing coastal erosion (e.g., Lantuit \& Pollard, 2008), or conversely, by promoting rapid progradation of deltas due to glacial ice mass loss (e.g., Bendixen et al., 2017). Fjord-head deltas constitute the main transition zones where sediment, fossil, and modern organic carbon (Galy et al., 2008; Smith et al., 2015) and contaminants (e.g., Perner et al., 2010) transit to reach deeper marine environments through river-generated density flows such as turbidity currents. Hence, rapid changes in coastal dynamics have a direct impact on these fluxes and strongly affect the nearshore environment and other associated processes in the deeper segments of the fjords, such as sediment distribution, benthos development (Syvitski et al., 1989), or the burial of organic carbon, which plays a crucial role in controlling $\mathrm{O}_{2}$ and $\mathrm{CO}_{2}$ concentrations (Smith et al., 2015).

Despite the importance of turbidity currents in the transfer of sediment and carbon to deeper-water ecosystems (e.g., Biscara et al., 2011), remarkably little information exists on sediment transport processes on highlatitude deltas due to a lack of high-resolution bathymetric data and in situ monitoring. In the eastern Baffin Island region (Canada; Figure 1), the links between the pattern of ongoing glacial retreat (Lenaerts et al., 2013) and sediment transport to the coast have the potential to provide a complete understanding of the consequences of deglaciation on sediment fluxes and partitioning in fjord systems. Therefore, the factors responsible for the presence of turbidity currents during deglaciation can be precisely identified. 

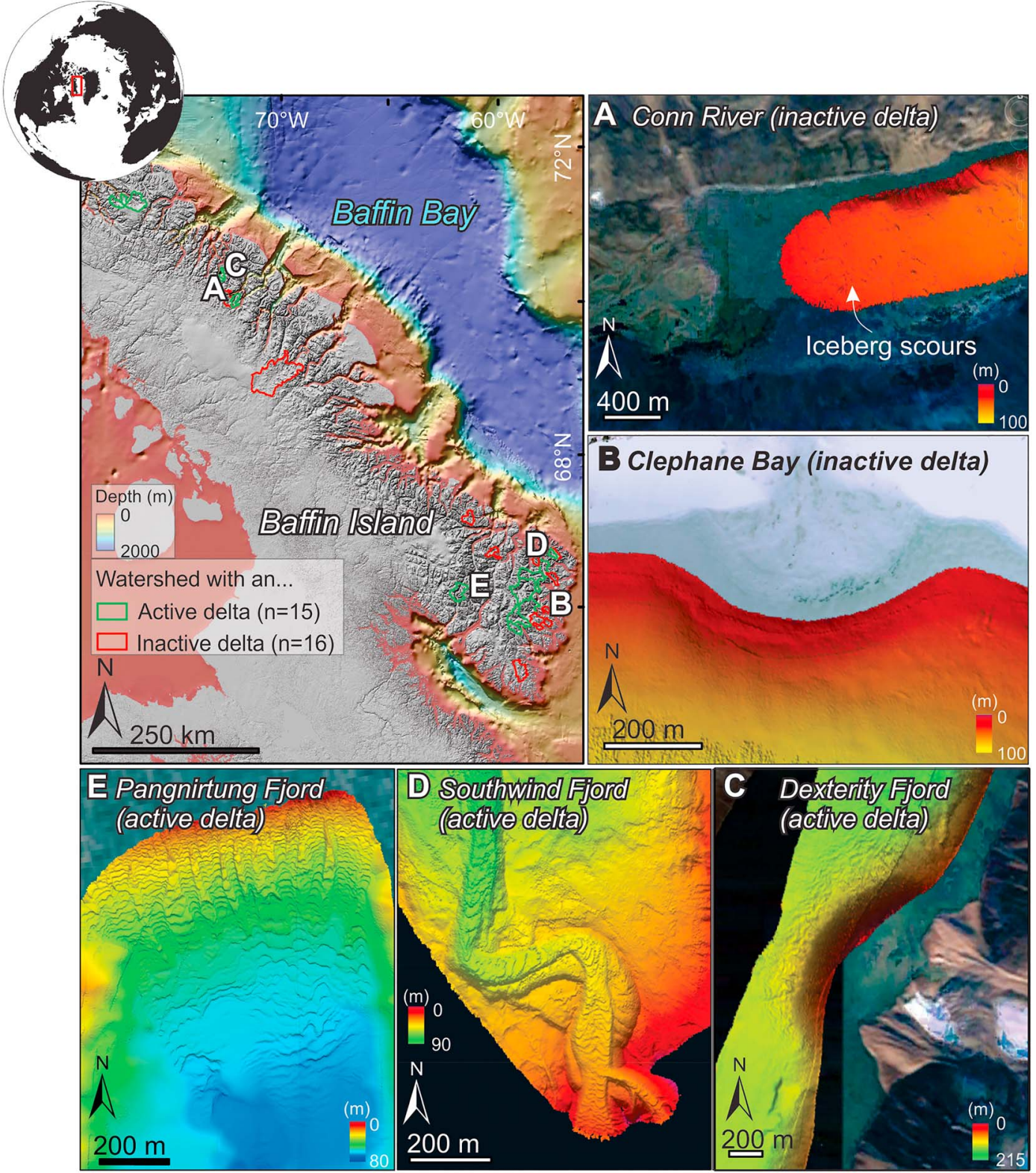

Figure 1. Distribution of the active and inactive delta watersheds along eastern Baffin Island with bathymetric examples of ( $\mathrm{a}$ and $\mathrm{b}$ ) inactive and (c-e) active deltas.

The effect of deglaciation on the progradation and activity of deltas is often limited to the stratigraphic record since these processes occur over hundreds to thousands of years (Dietrich et al., 2018; Winsemann et al., 2018). Therefore, the effect of the retreat pattern of glaciers on the deltaic processes is often based on outcrop studies or from the interpretation of sediment cores (e.g., Lonne \& Nemec, 2004; Normandeau et al., 2017). Eastern Baffin Island, like many other Arctic and Antarctic regions (e.g., Velicogna, 2009), is experiencing ongoing glacial retreat and presents a complete range of deglaciation stages: from marine-terminating glaciers to complete glacial retreat from watersheds. These different settings allow us to understand variations in sediment supply and its effect on deltaic progradation and the occurrence of turbidity currents. These variations can then be conceptualized into a temporal framework, from glaciarized watersheds (i.e., currently with glacial ice) to their complete deglaciation. The modern environments of eastern Baffin Island allow us to understand not only the factors controlling the occurrence of turbidity currents but also the effect of the retreat pattern of glaciers on deltaic activity. 
Here we present the results of extensive mapping of the submarine geomorphology of 31 fjord river mouths using high-resolution $(\leq 5-\mathrm{m})$ multibeam bathymetry data and characterize their relationship to glaciological and hydrological components of their watershed (Figure 1). The objectives of this study are threefold. First, the linkages between submarine sedimentary processes and the glaciological and hydrological components of watersheds allow for a precise understanding of the factors controlling the occurrence of turbidity currents on fjord deltas. Second, the different stages of deglaciation between watersheds allow us to build a temporal framework for the effect of the retreat pattern of glaciers on deltaic activity and the occurrence of turbidity currents. Third, based on the established controls on the presence of turbidity currents, we can predict where these processes are likely to be active for every fjord in eastern Baffin Island and speculate on future trends. Our findings have implications for the interpretation of past (Holocene and older) deglaciation sequences and for the assessment of coastal dynamics of areas currently affected by glacial retreat worldwide.

\section{Material and Methods}

\subsection{Data Sets}

This study is based on the analysis of bathymetric data sets collected on the Research Vessel Nuliajuk in 2012-2014 and the Canadian Coast Guard Ship Amundsen between 2006 and 2014. The multibeam bathymetric data were processed at a $<5-\mathrm{m}$ resolution in order to visualize the presence or absence of sediment waves on delta fronts, at river mouths, or the presence of drowned deltas. Thirty-one river mouths were mapped in this manner along the fjords of eastern Baffin Bay (Figure 1; e.g., Hughes-Clarke et al., 2015).

For each river mouth, watersheds were created using watershed analysis tools in ArcGIS and using the Baffin Island digital elevation model (25-m horizontal resolution) from the Canadian Digital Elevation Model (CDEM; Figure 2). For each watershed, glaciological and hydrological characteristics were extracted using zonal statistics in ArcGIS (Figure 2). The area $\left(\mathrm{m}^{2}\right)$ of the watersheds (Figure $2 \mathrm{~b}$ ) was calculated along with glacial ice area (Figure 2c), from the Randolf Glacier Inventory (Pfeffer et al., 2014), and glacial ice velocity (Figure 2d; Van Wychen et al., 2015; m/year). The sum of glacial ice velocity (sum of pixels) was used in this study as a proxy for glacial erosion. Pixel sizes for the ice velocity were $100 \times 100 \mathrm{~m}^{2}$, and the sum of the velocity for all pixels within the watershed was calculated. The ice velocity data set covers $99 \%$ of the Randolf Glacier Inventory data set. Two watersheds were not fully covered by the glacial ice velocity data set, and thus, this parameter was ignored for those two watersheds. Lake area (Figure 2e) was calculated using the HydroShed Global Lake Database (Messager et al., 2016). Overall, the Global Lake Database was sufficient to cover all the lakes within 29 of the 31 watersheds studied in detail. Observation of lakes smaller than what the Global Lake Database provides $\left(<0.1 \mathrm{~km}^{2}\right)$ was added manually in two watersheds. For the predictive map (see section 4), the Global Lake Database was used without modification; therefore, lakes smaller than $0.1 \mathrm{~km}^{2}$ were not taken into account, which might necessitate small adjustments in the predictive mapping. Finally, rivers were classified using the Strahler classification and a threshold of 100 pixel was used to define a class 1 river (Figure 2f).

Watersheds were also created for all the lakes located within the fjord-delta watersheds, and data extracted from these subwatersheds were removed from the total watershed values, producing new adjusted watershed values that exclude lake sediment trapping (Figure $2 \mathrm{~g}$ ).

\subsection{Statistical Analyses}

Since distributions were nonnormal for most of the extracted parameters, a Wilcoxon-Mann-Whitney test was used to determine if active and inactive deltas had significant differences in watershed characteristic. This nonparametric test was used to test differences between two conditions (active versus inactive deltas) and glaciological and hydrological characteristics of watersheds (presence of glacial ice, ice velocity, river classification, etc.). A $P$ value $<0.05$ indicates a statistical difference between the two distributions (active and inactive deltas). In most instances, ties in the data sets were present, and thus, the values were slightly modified (using jitter in $R$ ) in order to compute exact $P$ values. An effect size was then calculated in $R$ to estimate the size of the effect observed following Field et al. (2012).

In addition to a Wilcoxon-Mann-Whitney test, the homogeneity of variance of the active and inactive deltas glaciological and hydrological parameters was compared. Since normal distributions could not be assumed 

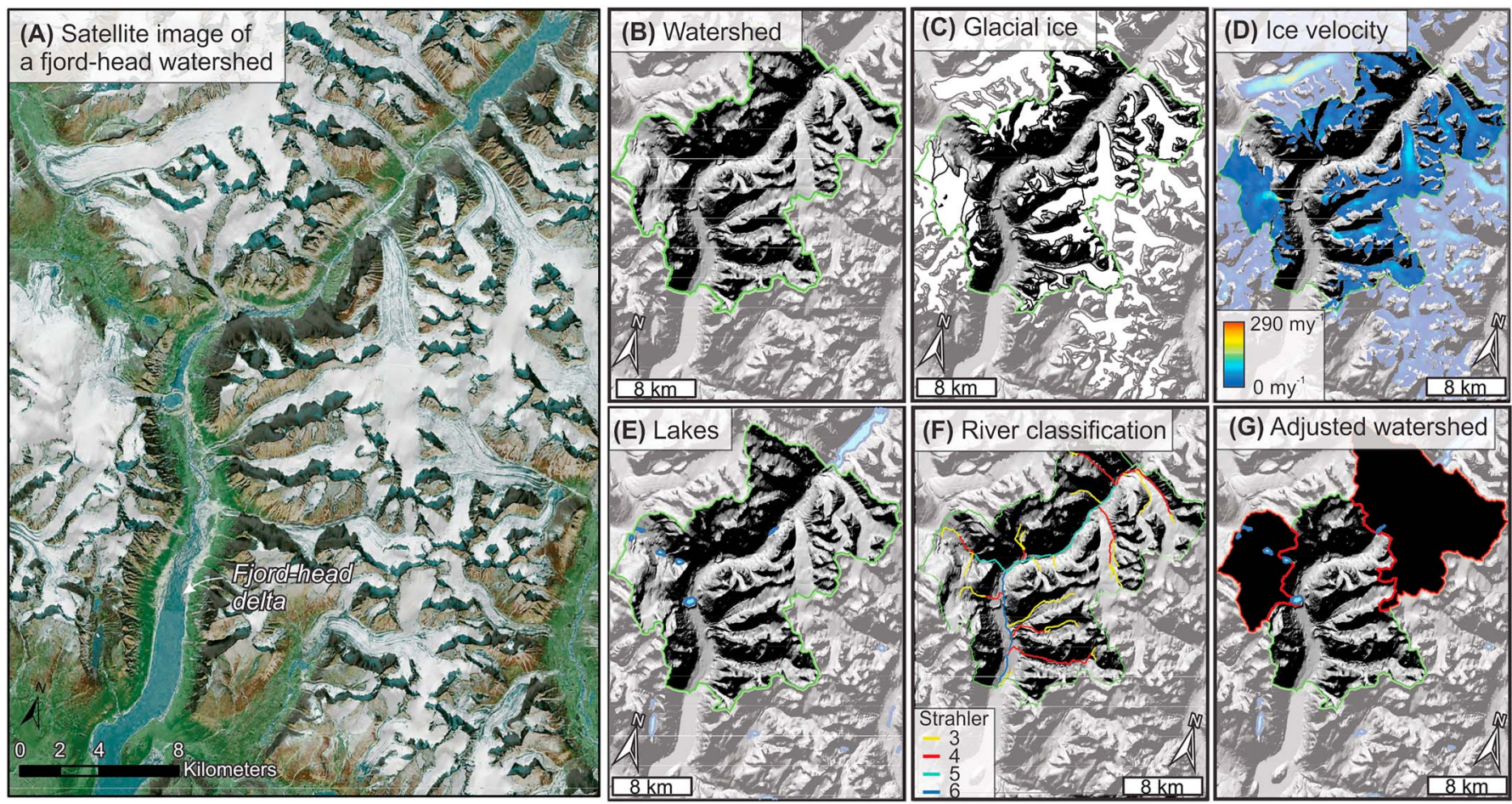

Figure 2. Method for the extraction of glaciological and hydrological data: (a) Satellite image of the Pangnirtung fjord-head delta and watershed. (b) Delimitation of its watershed (green line). (c) Extraction of glacial ice area within the watershed. (d) Extraction of glacial ice velocity within the watershed. (e) Extraction of the area of lakes within the watershed. (f) Extraction of river classification within the watershed. (g) Delimitation of the adjusted watersheds (green watershed excluding the red subwatersheds of lakes) from which the previous glaciological and hydrological characteristics were re-extracted.

for all data sets, a Fligner-Killeen test was used. A $P$ value $<0.05$ indicates a significant difference in variance between the two conditions.

\subsection{Approach: Sediment Waves as Indicators of Deltaic Activity}

The main terrestrial parameter driving nearshore fjord hydrodynamics is river discharge, which controls submarine delta activity by generating turbidity currents (Hughes Clarke, 2016; Syvitski, 1989). Active submarine deltas are here viewed through the prism of subaqueous sediment wave organization. In this study, submarine delta activity is therefore defined as the presence of recurring and energetic turbidity currents, triggered at the delta front, and flowing downslope. These turbidity currents typically form sediment waves, where their presence along delta slopes is used to assess if a particular delta is active (Figure 2). All active deltas with sediment waves are associated with well-developed subaerial deltas. On active deltas, sediment waves are mostly crescentic and are interpreted as upper-flow regime bedforms, probably cyclic steps (Cartigny et al., 2011; Hughes Clarke, 2016). Cyclic steps are sediment waves that migrate upstream and are formed by turbidity currents that recurrently undergo hydraulic jumps (Kostic et al., 2010). These types of sediment waves are known to be present on active delta slopes (Clare et al., 2016; Fricke et al., 2015; Hughes Clarke, 2016; Kostic et al., 2019; Normandeau et al., 2016); their presence indicates active processes (e.g., Hughes Clarke, 2016; Normandeau et al., 2014; Smith et al., 2005). Therefore, the presence of sediment waves indicates that turbidity currents occur on the delta slopes (i.e., active deltas) although their frequency is unknown. Inactive deltas were defined as river mouths where turbidity currents do not to occur. Inactive deltas were identified either by the absence of a well-developed subaerial delta linked to the absence of submarine sediment waves extending in deeper waters or by the observation of a nearshore drowned delta. Inactive deltas often form bays where shoreline retreat occurs as wave erosion outpaces sediment supply from rivers.

Repeat bathymetric surveys of three submarine deltas in Oliver Sound (northeast Baffin Island) in 2006 and 2008 (Figure 3) and Southwind fjord between 2013 and 2018 (data not shown) show that sediment waves 

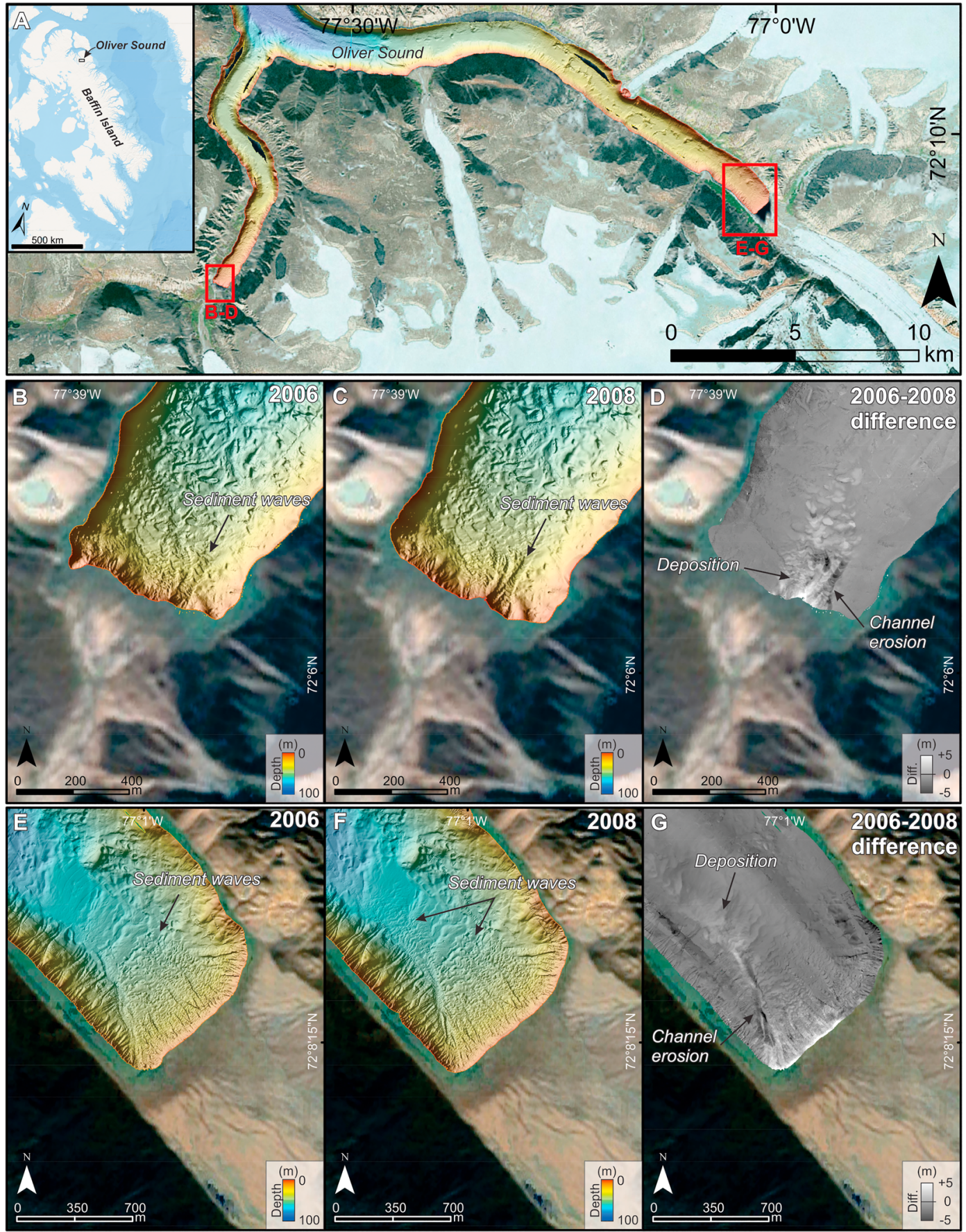

Figure 3. Examples of recurring turbidity currents leading to the migration of sediment waves (cyclic steps) on two fjordhead deltas between 2006 and 2008. (a) Location of Oliver Sound and the fjord-head deltas. (b) Bathymetry of western Oliver Sound delta in 2006. (c) Bathymetry of western Oliver Sound delta in 2008. (d) Elevation difference map of western Oliver Sound between 2006 and 2008 illustrating channel erosion and the migration of sediment waves. (e) Bathymetry of eastern Oliver Sound delta in 2006. (f) Bathymetry of eastern Oliver Sound delta in 2008. (g) Elevation difference map of eastern Oliver Sound between 2006 and 2008 illustrating channel erosion and the migration of sediment waves.

migrated over these 2-year periods. Figures 3a-3g show the morphology of two delta fronts in 2006 and 2008 along with the differences in bathymetry between the 2 years. These data clearly show that the sediment waves have migrated between the 2 years and that channel erosion occurred. These seafloor changes confirm that the presence of sediment waves indicates recurring turbidity currents, and therefore, active 


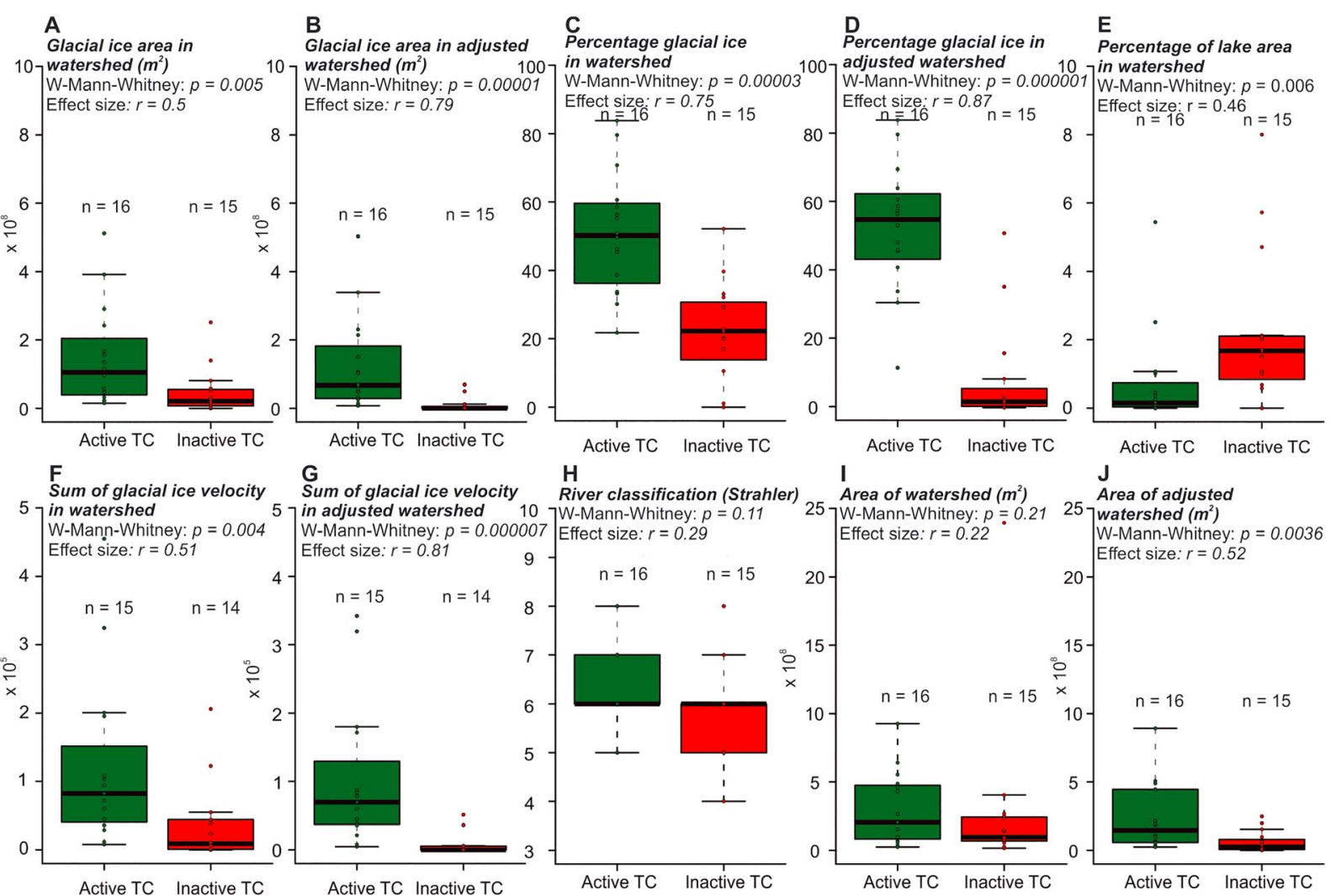

Figure 4. Boxplots of the glaciological and hydrological parameters controlling turbidity currents (TC) in fjord-head deltas. (a) Glacial ice area in watershed, (b) glacial ice area in adjusted watershed, (c) percentage of glacial ice in watershed, (d) percentage of glacial ice in adjusted watershed, (e) percentage of lake area in watershed, (f) sum of glacial ice velocity in watershed, (g) sum of glacial ice velocity in adjusted watershed, (h) river classification, (i) area of watershed, and (j) area of adjusted watershed were all tested against the presence or absence of sediment waves (TC or No TC). The percentage of glacial ice in adjusted watershed (d) was found to be the main controlling factor on the presence of sediment waves and therefore on the occurrence of turbidity currents in fjords.

submarine deltas. These types of sediment waves and seafloor changes are known to be the effect of turbidity currents (Corella et al., 2016; Hage et al., 2018; Normandeau et al., 2016) and cannot be attributed solely to oceanographic processes. The absence of sediment waves on a delta or the absence of a delta in other cases conversely indicates that turbidity currents do not occur.

\section{Results}

\subsection{Glaciological and Hydrological Parameters of Active and Inactive Deltas}

High-resolution multibeam bathymetric imagery available for 31 river mouths and deltas reveals 16 active and 15 inactive deltas (Figure 1). Glacial ice in the watershed is shown to be an important factor in the occurrence of turbidity currents (Figures $4 \mathrm{a}-4 \mathrm{~d}$ ). The median percentage of glacial ice in watersheds of active deltas is $50 \%\left(Q_{1}=37 \%, Q_{3}=60 \%\right)$ compared to $22 \%\left(Q_{1}=14 \%, Q_{3}=31 \%\right)$ for inactive ones (Figure $\left.4 \mathrm{c}\right)$. In order to assess if active and inactive deltas have significantly different glaciological and hydrological settings in their watershed, a nonparametric Wilcoxon-Mann-Whitney test was used. The percentage of glacial ice in the watershed is a critical factor controlling the nearshore presence of turbidity currents in fjords $(P<0.001, r$ $=0.75$; Table 1 and Figure $4 \mathrm{c})$. Watersheds devoid of glacial ice $(n=2)$ have inactive deltas, whereas watersheds with glacial ice can be active or inactive depending on past patterns of glacial retreat. Some inactive deltas have a comparable percentage of glacial ice in their watershed to active deltas (Figure 4c).

In order to evaluate the effectiveness of lakes in trapping sediments, the percentage of watershed covered by lakes was calculated and is a significant parameter between active and inactive deltas (Figure 4e). Lake subwatersheds were thus removed from all the watersheds, which provided new adjusted watersheds with a median percentage of glacial ice of $55 \%\left(Q_{1}=44 \%, Q_{3}=61 \%\right)$ for active deltas and $1 \%\left(Q_{1}=0.1 \%, Q_{3}=5 \%\right)$ 
Table 1

Factors Controlling the Presence of Turbidity Currents on Fjord Deltas

\begin{tabular}{lccc}
\hline Variable & Wilcoxon-Mann-Whitney $P$ value & Effect size $(r)$ & Fligner-Killeen $P$ value \\
\hline Percentage glacial ice in adjusted watershed & 0.000001 & 0.87 & 0.81 \\
Sum of glacial ice velocity in adjusted watershed & 0.000007 & 0.79 & 0.03 \\
Glacial ice area in adjusted watershed & 0.00001 & 0.75 & 0.001 \\
Percentage glacial ice in watershed & 0.00003 & 0.52 & 0.51 \\
Area of adjusted watershed & 0.0036 & 0.58 & 0.003 \\
Sum of glacial ice velocity in watershed & 0.004 & 0.46 & 0.04 \\
Glacial ice area in watershed & 0.005 & 0.01 & 0.04 \\
Percentage lake area in watershed & 0.006 & 0.046 \\
River classification (Strahler) & 0.11 & 0.22 \\
Area of watershed & 0.21 & 0.14 \\
\hline
\end{tabular}

Note. A Wilcoxon-Mann-Whitney test was used to compare active versus inactive deltas. Percentage of glacial ice is the main controlling factor and the effect size increases when taking lakes as efficient sediment traps into consideration (adjusted watersheds). The Fligner-Killeen test checks for homogeneity of variance between the distributions and indicates if the difference in variance is significant $(P<0.05)$ or not.

for inactive ones (Figure 4d). When excluding the subwatersheds that flow into lakes from delta watersheds, active deltas have watersheds with significantly more glacial ice than inactive deltas $(P<0.001, r=0.87$; Table 1 and Figure 4d). The percentage of glacial ice in the subwatersheds of lakes explains the inactivity of the deltas with high percentage of glacial ice in their total watershed. Additionally, a Fligner-Killeen test shows that there is no significant difference between the variances of glacial ice in active and inactive delta watersheds when comparing their total watershed $P=(0.58)$ but that there is such difference when comparing glacial ice in the adjusted watershed $(P=0.03$; Table 1$)$. This significant difference between the variances indicates that watersheds of active deltas have higher variance of glacial ice than the inactive deltas, as expressed in Figure $4 \mathrm{~d}$ where the percentage of glacial ice in adjusted watersheds for inactive deltas largely remains below $10 \%$ but varies between 30 and $90 \%$ for active deltas. Furthermore, glacial ice velocity (Figures $4 \mathrm{f}$ and $4 \mathrm{~g}$ ), which is used as a proxy for glacial erosion (e.g., Overeem et al., 2017), is significantly higher in active delta watersheds than in inactive ones, especially within adjusted watersheds (Figure 4g; $P<0.001, r=0.81$ ). Other parameters such as river classification $(P=0.11$, $r=0.29$; Figure $4 \mathrm{~h}$ ), which is a proxy for river discharge (Strahler, 1957), or area of watershed $(P=0.21$, $r=0.22$; Figure 4i), show no significant differences between the active and inactive delta watersheds (Table 1). The area of adjusted watershed becomes, however, a significant parameter $(P=0.0036, r=0.52$; Figure $4 \mathrm{j}$ ) because, in some cases where lakes are formed near the river mouth, the watershed area is diminished by $95 \%$ when excluding lake sub watersheds.

\section{Discussion}

\subsection{Factors Controlling the Occurrence of Turbidity Currents}

This study demonstrates the different glaciological and hydrological parameters that have an effect on the occurrence of turbidity currents on fjord deltas. Recently, Pope et al. (2019) showed that a stable ice front was necessary for the formation of turbidity current channels at marine-terminating glaciers and that large watersheds increased the likelihood of turbidity currents. Gales et al. (2018) have also shown shown that the watershed area and river discharge control the type of deltas created, that is, small Gilbert-type deltas or deltas with long-running channels. Our results show no significant differences between small and large watersheds on the occurrence of turbidity currents. Similarly, river classification, which is used as a proxy for river discharge, does not affect the occurrence of turbidity currents at river mouths, although it may affect the development of submarine channels (Gales et al., 2018). However, river discharge will be affected not only by river classification but also by glacial meltwater in watersheds comprising glacial ice. Therefore, river classification between glaciarized and nonglaciarized watersheds is probably not comparable.

The presence of glaciers in the watersheds exerts a significant control over the occurrence of turbidity currents, which indicates that the presence of glaciers allows for the supply of sediment to deltas. Glacial ice area and percentage of glacial ice are both important for the occurrence of turbidity currents. However, the percentage of glacial ice in the watershed exerts a slightly stronger influence, likely because it 
provides an estimation of the proximity of the source of sediment (i.e., glacial erosion); a higher percentage of glacial ice covers a larger area of the watershed, thereby providing a source of sediment close to the delta. A closer source of sediment reduces the likelihood of sediment storage within the watershed. Conversely, small glacial ice percentages are more likely to indicate a source of glacial erosion farther upstream in the watershed, thereby increasing the likelihood of watershed sediment storage.

The differences between total and adjusted watersheds show the influence of lakes on preventing the delivery of sediment to deltas. These differences are most clearly illustrated when looking at glacial ice percentage in active and inactive delta watersheds. Active deltas all contain a similar percentage of glacial ice in their total and adjusted watersheds. However, although the percentage of glacial ice mostly varies between 14 and $31 \%$ in inactive delta watersheds, it drops to $0-5 \%$ in the adjusted watersheds. A similar trend is observed when examining the glacial ice velocity, which is used as a proxy for glacial erosion, since both parameters are linked. These values clearly show that lakes are efficient in trapping sediment and preventing the progradation of deltas and the formation of turbidity currents. The proximity of the ice margin to the delta hence reduces the likelihood for sediment to encounter and then be trapped in a lake.

\subsection{The Retreat Pattern of Glaciers Controls the Occurrence of Turbidity Currents}

The different deglaciation stages of the watersheds of Baffin Island allow us to better understand temporal trends in the evolution of deltas in glaciated settings and provide a conceptual model for the occurrence of turbidity currents in high-latitude environments. Some watersheds are almost fully glaciarized, whereas others are completely deglaciated. Examining the differences in deltaic processes and activity for this wide range of glaciarized settings allows us to understand the temporal variations in sediment supply and propose a model for the evolution of a single delta/watershed during the retreat of glaciers (Figure 5). This model begins when ice-margins become land-based and ends when ice-margins have completely retreated from the watershed.

The results presented here demonstrate the role played by glacial erosion and the retreat pattern of glaciers across watersheds in modifying the type of sediment supply to fjords (Figure 5). The supply of sediment from glacial erosion is assumed to slowly decrease with time-as the sum of glacial ice velocity is used as a proxy for glacial erosion-but to remain relatively high during onland glacier retreat (Figure 5a), as suggested by the presence of turbidity currents on deltas with watersheds comprising from 30 to $90 \%$ glacial ice. Glacial erosion and glacial meltwaters provide large volumes of sediment when there is a direct connection between glacier and fjord-delta, which allows turbidity currents to form. However, during the retreat of the glaciers, proglacial lakes can form because of moraine damming, glacial overdeepening, isostatic flexure, or structural inheritance (Carrivick \& Tweed, 2013; Dietrich et al., 2017) and significantly alter the delivery of sediment to the ocean. When lakes form, sediment supply to the fjord-head delta decreases significantly as sediment is trapped upstream in lakes, modifying the hydrodynamics of the marine nearshore environment due to sediment starvation (Figures $5 \mathrm{a}$ and $5 \mathrm{c}$ ). Both small and large lakes act the same way in trapping sediment upstream of the delta. Sediment starvation is not due to reduced sediment supply from the glaciers but is due to sediment not reaching the coast. The production of meltwater remains constant during that time, but lakes prevent the supply of sediment to the delta. These results show the importance of glacial erosion and sediment supply compared to meltwater discharge for the occurrence of turbidity currents. Because of sediment starvation, some deltas appear to have been significantly eroded, forming bays, while upstream lakes in the watershed are being filled with sediment (Figure 5c). However, once sediment completely fills the lakes, which appears to have occurred in some watersheds (Figure 5d), deltas can be reactivated in the long term since the course of the river down to the fjord is re-established (Figure 5). Hence, although all sizes of lakes are efficient in trapping sediment, the size of lakes influences the time period during which sediment starvation on fjord deltas occurs. Finally, when glaciers retreat from the watersheds, there is often no longer enough sediment supplied through glaciofluvial rivers to generate turbidity currents, which leads to the cessation of turbidity currents and the erosion of the deltas (Figure 5a).

Recent studies have shown that delta progradation is rapid in watersheds affected by glacial ice mass loss even during relative sea level rise (Bendixen et al., 2017), which leads us to conclude that shallow bays or shelves, in some cases formed by a drowned former delta plain and which are not prone to the formation of turbidity currents, would be quickly filled by the prograding deltas, after which turbidity currents would form in deeper environments. Therefore, the presence of a shallow bay or shelf in nearshore fjords does not preclude in the long term the formation of turbidity currents after rapid filling of the shallow nearshore 
A

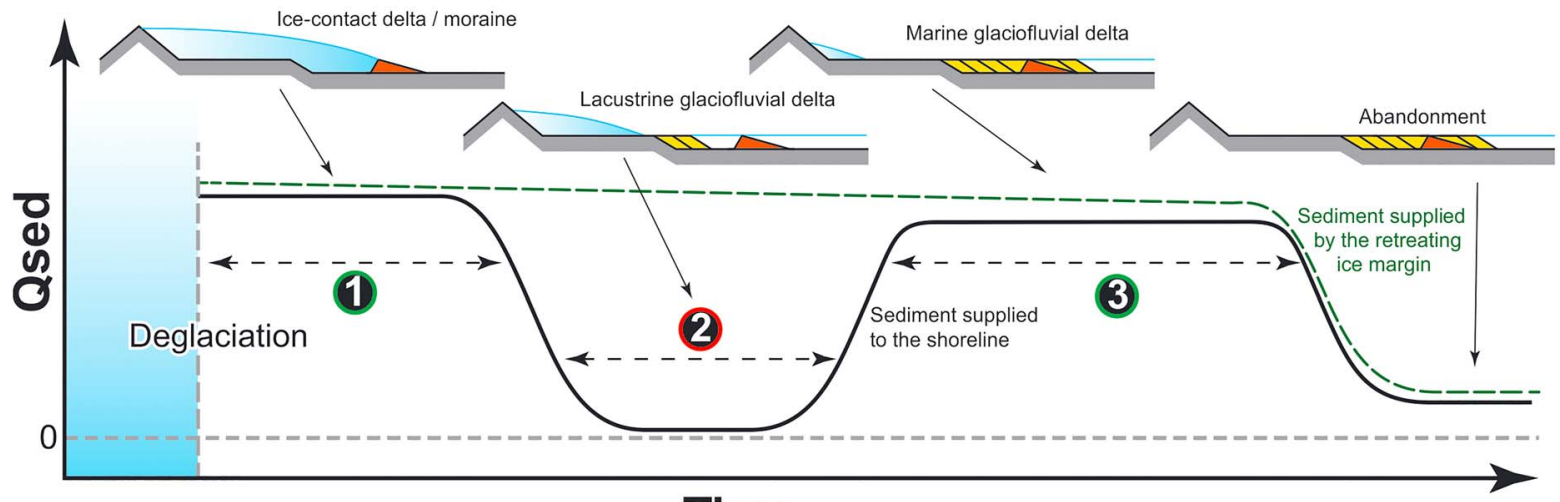

Time
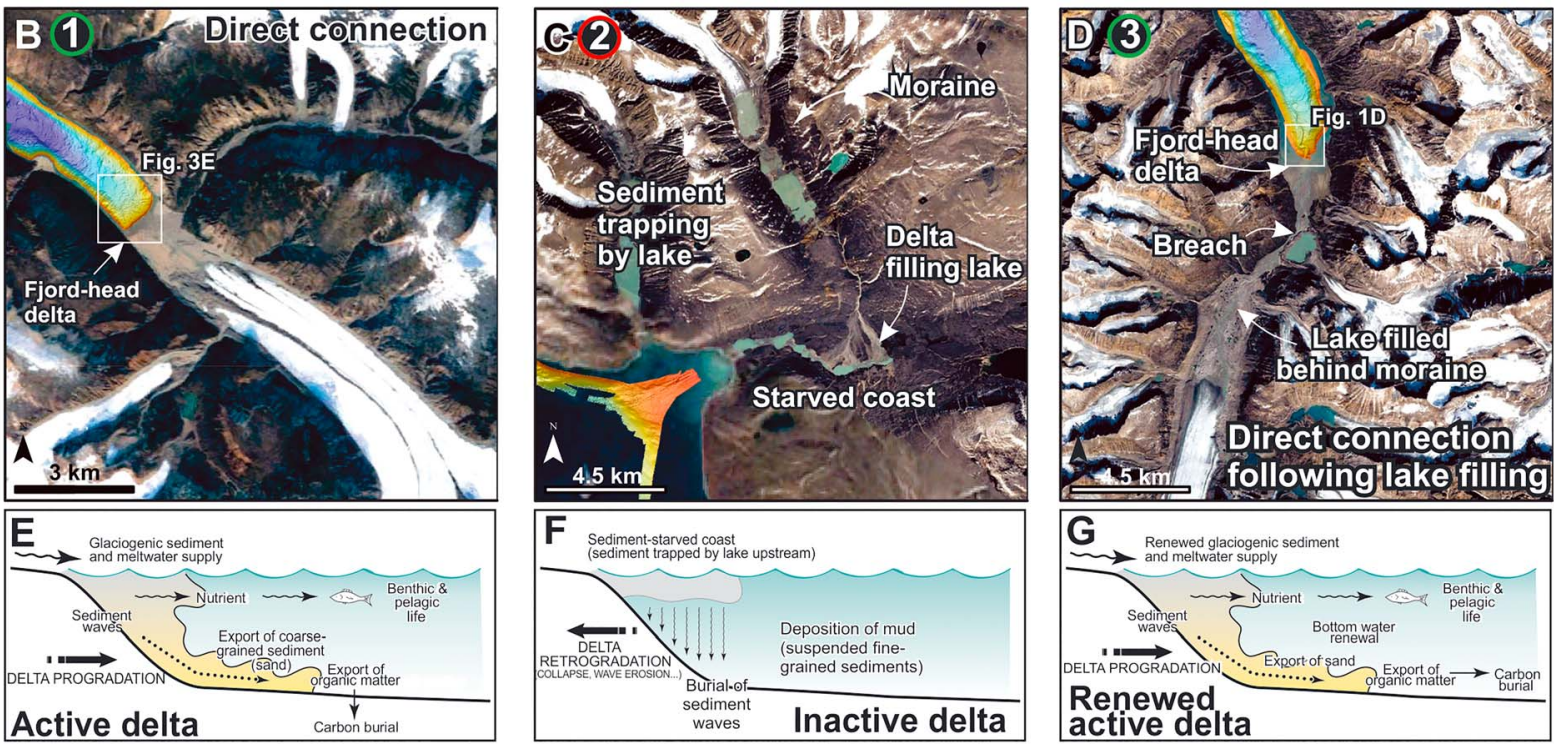

Figure 5. Effect of watershed characteristics on deltaic activity. (a) Proposed model for the occurrence of turbidity currents during glacier retreat: (b and e) (1) A direct connection between glacial erosion and the delta will lead to the occurrence of turbidity currents. (c, and f) (2) The presence of a lake caused by glacial retreat (e.g., by moraine damming or glacial overdeepening) will alter the delivery of sediment to the delta. ( $\mathrm{d}$ and g) (3) However, if the lake is filled, the connection will be re-established, leading to the reactivation of turbidity currents.

environment. Possible limitations to this model nonetheless include the depth of the prodelta during the transition from an inactive delta to an active one (i.e., the time it takes for deltas to fill shallow bays). Bedrock lithology also affects the erosion by glacial or fluvial processes and may influence the volume of sediment transported to fjords and the occurrence of turbidity currents.

\subsection{Can We Predict the Occurrence of Turbidity Currents From Glaciological and Hydrological Watershed Characteristics?}

Based on the results of this study, the terrestrial glaciological and hydrological characteristics of watersheds can be used to identify fjords where turbidity currents are likely, possibly, or unlikely to be presently occurring. The percentage of glacial ice within the adjusted watersheds (excluding lake subwatersheds) proved to be a significant parameter for the presence of turbidity currents (Table 1). Therefore, this parameter was used to predict the location of active deltas for 644 rivers in fjords of eastern Baffin Island (Figure 6) where (1) less than $10 \%$ glacial ice in adjusted watershed suggests that the deltas are inactive or absent (called "low likelihood" in Figure 6b), (2) between 10 and 20\% glacial ice suggests that they are possibly active (called "Medium likelihood" in Figure 6b), and (3) more than $20 \%$ glacial ice in adjusted watersheds suggests that the deltas are active (called "High likelihood" in Figure 6b). When applied to the 31 known river mouths, these thresholds yield a $6.5 \%$ error, where two inactive deltas were mistakenly interpreted as active. In these two cases, other 


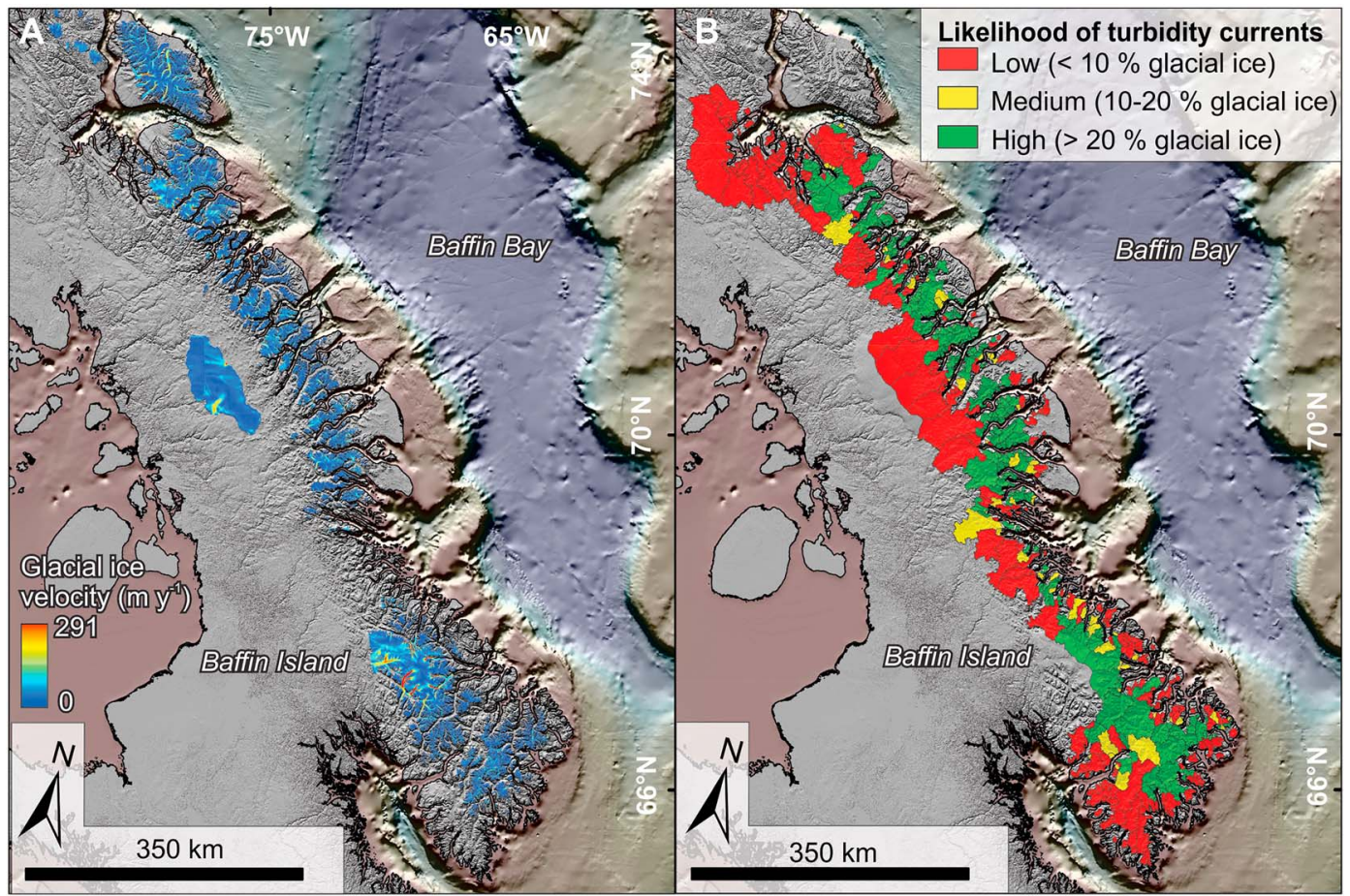

Figure 6. (a) Distribution of glacial ice and glacial ice velocity in eastern Baffin Island. (b) Predictive map of fjord deltas with currently occurring turbidity currents. Very likely active turbidity currents (High in b) have $>20 \%$ glacial ice in their adjusted watersheds (excluding lake subwatershed). Possibly active deltas (Medium in b) have 10-20\% glacial ice in their adjusted watersheds (in yellow). Inactive deltas (Low in b) have less than $10 \%$ glacial ice in their adjusted watersheds (in red).

parameters such as moraine damming or storing of sediment within the sediment-routing system appear to play a role but could not be quantified. Using the percentage of glacial ice in adjusted watersheds is thus a strong proxy for predicting where turbidity currents occur in high-latitude fjords.

Recent studies have suggested that glacier-derived sediment flux controls the progradation of deltas (Bendixen et al., 2017; Dietrich et al., 2017). Our findings reveal that the pattern of glacial retreat, that is, the formation of lakes due to moraine damming or glacial overdeepening, is more important than the simple presence/absence of a glacier in the watershed on the occurrence of turbidity currents. Of the 644 river mouths in the fjords of eastern Baffin Island, 48\% likely have no deltas or inactive deltas, $9 \%$ have deltas that are possibly active, and $43 \%$ likely have active deltas. Although $60 \%$ of the deltas have an elevated proportion of glacial ice ( $>10 \%)$ in their watersheds, only $52 \%$ possibly or likely have turbidity currents at their fronts because of the effect of lake trapping that prevents sediment delivery to the fjords. It is however important to note that this likelihood of the occurrence of turbidity currents (Figure $6 \mathrm{~b}$ ) is only applicable in the modern configuration of lake distribution, which inherently evolves through time.

\subsection{Possible Implications of Ongoing and Future Glacier Retreat}

As retreat of glaciers is ongoing, their pattern of retreat may modify the future hydrological and glaciological characteristics, which will then have a direct impact on the occurrence of turbidity currents in fjords. For example, if there is a stillstand during the retreat of glaciers, it is likely to construct a frontal moraine, which may then form a moraine-damned proglacial lake that traps sediment. Conversely, if the retreat of glaciers is continuous, the formation of a proglacial lake is less likely, allowing continuous sediment delivery to fjorddeltas. Currently, studies have shown that the retreat of glaciers and ice mass loss has accelerated in the beginning of the 21st century due to higher summer temperatures with little change in annual precipitation (Gardner et al., 2012) and that this ice mass loss appears irreversible until the end of the century (Lenaerts et al., 2013). If this accelerated ice mass loss continues as predicted, we speculate that moraine-damned lakes will be less likely to form, thus enhancing in the short term the occurrence of turbidity currents in Baffin 
fjords. Some existing lakes may be filled, which will allow some deltas to be reactivated. However, if ice mass loss continues until no glaciers remain, the occurrence of turbidity currents will cease and will have an abrupt effect on the hydrodynamics of fjords.

The retreat pattern of glaciers on land not only has an influence on turbidity currents but it also affects carbon and nutrient transport to fjords (e.g., Hopwood et al., 2018). When lakes are absent in the sedimentrouting system, carbon and nutrients are easily transported to fjords, which then act as traps (Smith et al., 2005). On the other end, the presence of lakes can significantly alter the transport of carbon and nutrients to fjords, which can remain, at least partly, trapped inland. Turbidity currents are an efficient mechanism for the dispersal and distribution of carbon and nutrients in fjords. If deltas become inactive and erode (retreat) due to the formation of lakes upstream, carbon may not be as efficiently distributed in fjord systems. Therefore, the future pattern of glacial retreat will affect the transport of carbon and nutrients and the hydrodynamics of fjord systems.

\section{Conclusions}

This study used the various stages of deglaciation of eastern Baffin Island to illustrate the role of the retreat pattern of glaciers on the activity of deltas through the occurrence of turbidity currents. We show that the supply of sediment to fjords, which is necessary for the formation of turbidity currents, is controlled by glacial erosion and glacial meltwaters and hampered by the presence of lakes in the sediment-routing system. Glaciers on land are a necessary condition for the erosion of bedrock and the supply of large volumes of sediment through meltwater to coastal and nearshore environments, whereas lakes can prevent delivery to the fjords. The factors controlling the occurrence of turbidity currents were then conceptualized in a temporal framework since eastern Baffin Island comprises watersheds which are fully glaciarized to fully deglaciated. These stages of deglaciation were thus used to demonstrate the evolution of a retreating glacier and the formation of lakes on the nonlinear activity of deltas (Figure 5). Although this study is based on the modern environment, it can be used as a way to further our understanding of the effects of Late Pleistocene/Early Holocene deglaciation on fjord sedimentation and to estimate future occurrence of turbidity currents in response to climate change.

Since the formation of lakes during glacial retreat is highly variable in space and time, the timespan of delta activity is hard to predict. Watersheds where glaciers are retreating, which is a general trend in the Arctic due to climate change (Lenaerts et al., 2013), may develop proglacial lakes in the near future, which will suddenly alter the fjord nearshore hydrodynamics. Once lakes are filled, deltaic sedimentary processes may become active again. The acceleration of ice mass loss however suggests that morainedamned lakes are less likely to form in the future in the absence of glacial stillstands, potentially enhancing temporarily the occurrence of turbidity currents in Baffin fjords. Finally, following the retreat of the glaciers from the watersheds, sediment supply will abruptly drop due to cessation of glacial supply or rerouting of glacial sediments and meltwaters to adjacent basins. Future patterns of glacial retreat will dictate the nonlinear nearshore hydrodynamics of fjords and its impact on carbon burials and ecosystems.

\section{Acknowledgments}

The authors wish to thank ArcticNet for the multibeam data collection. The multibeam data collected for this study are available at http://www.omg.unb. ca/Projects/Arctic/. The extracted glaciological and hydrological data are available in the supporting information. This study was funded by the Geological Survey of Canada. We thank two anonymous reviewers and the Editors for their comments that improved the clarity of the manuscript.

\section{References}

Bendixen, M., Iversen, L. L., Bjørk, A. A., Elberling, B., Westergaard-Nielsen, A., Overeem, I., et al. (2017). Delta progradation in Greenland driven by increasing glacial mass loss. Nature, 550(7674), 101-104. https://doi.org/10.1038/nature23873

Biscara, L., Mulder, T., Martinez, P., Baudin, F., Etcheber, H., Jouanneau, J. M., \& Garlan, T. (2011). Transport of terrestrial organic matter in the Ogooué deep sea turbidite system (Gabon). Marine and Petroleum Geology, 28(5), 1061-1072. https://doi.org/10.1016/j. marpetgeo.2010.12.002

Carrivick, J. L., \& Tweed, F. S. (2013). Proglacial lakes: Character, behaviour and geological importance. Quaternary Science Reviews, 78, 34-52. https://doi.org/10.1016/j.quascirev.2013.07.028

Cartigny, M. J., Postma, G., van den Berg, J. H., \& Mastbergen, D. R. (2011). A comparative study of sediment waves and cyclic steps based on geometries, internal structures and numerical modeling. Marine Geology, 280(1-4), 40-56. https://doi.org/10.1016/j. margeo.2010.11.006

Clare, M. A., Clarke, J. H., Talling, P. J., Cartigny, M. J., \& Pratomo, D. G. (2016). Preconditioning and triggering of offshore slope failures and turbidity currents revealed by most detailed monitoring yet at a fjord-head delta. Earth and Planetary Science Letters, 450, 208-220. https://doi.org/10.1016/j.epsl.2016.06.021

Corella, J. P., Loizeau, J. L., Kremer, K., Hilbe, M., Gerard, J., Dantec, N., et al. (2016). The role of mass-transport deposits and turbidites in shaping modern lacustrine deepwater channels. Marine and Petroleum Geology, 77, 515-525. https://doi.org/10.1016/j. marpetgeo.2016.07.004 
Dietrich, P., Ghienne, J. F., Lajeunesse, P., Normandeau, A., Deschamps, R., \& Razin, P. (2018). Deglacial sequences and glacio-isostatic adjustment: Quaternary compared with Ordovician glaciations, Special Publications (Vol. 475, pp. 149-179). London: Geological Society. https://doi.org/10.1144/SP475.9

Dietrich, P., Ghienne, J. F., Normandeau, A., \& Lajeunesse, P. (2017). Reconstructing ice-margin retreat using delta morphostratigraphy. Scientific Reports, 7(1), 16936. https://doi.org/10.1038/s41598-017-16763-x

Field, A., Miles, J., \& Field, Z. (2012). Discovering statistics using R. London, UK: Sage Publications.

Ford, J. D., Couture, N., Bell, T., \& Clark, D. G. (2017). Climate change and Canada's north coast: Research trends, progress, and future directions. Environmental Reviews, 26(1), 82-92.

Fricke, A. T., Sheets, B. A., Nittrouer, C. A., Allison, M. A., \& Ogston, A. S. (2015). An examination of Froude-supercritical flows and cyclic steps on a subaqueous lacustrine delta, Lake Chelan, Washington, USA. Journal of Sedimentary Research, 85(7), 754-767. https://doi. org/10.2110/jsr.2015.48

Gales, J. A., Talling, P. J., Cartigny, M. J., Hughes Clarke, J., Lintern, G., Stacey, C., \& Clare, M. A. (2018). What controls submarine channel development and the morphology of deltas entering deep-water fjords? Earth Surface Processes and Landforms, 44(2), 535-551. https:// doi.org/10.1002/esp.4515

Galy, V., France-Lanord, C., \& Lartiges, B. (2008). Loading and fate of particulate organic carbon from the Himalaya to the GangaBrahmaputra delta. Geochimica et Cosmochimica Acta, 72(7), 1767-1787. https://doi.org/10.1016/j.gca.2008.01.027

Gardner, A., Moholdt, G., Arendt, A., \& Wouters, B. (2012). Accelerated contributions of Canada's Baffin and Bylot Island glaciers to sea level rise over the past half century. The Cryosphere, 6(5), 1103-1125. https://doi.org/10.5194/tc-6-1103-2012

Gardner, A. S., Moholdt, G., Wouters, B., Wolken, G. J., Burgess, D. O., Sharp, M. J., et al. (2011). Sharply increased mass loss from glaciers and ice caps in the Canadian Arctic Archipelago. Nature, 473(7347), 357-360. https://doi.org/10.1038/nature10089

Hage, S., Cartigny, M. J., Clare, M. A., Sumner, E. J., Vendettuoli, D., Hughes Clarke, J. E., et al. (2018). How to recognize crescentic bedforms formed by supercritical turbidity currents in the geologic record: Insights from active submarine channels. Geology, 46(6), 563-566. https://doi.org/10.1130/G40095.1

Hopwood, M. J., Carroll, D., Browning, T. J., Meire, L., Mortensen, J., Krisch, S., \& Achterberg, E. P. (2018). Non-linear response of summertime marine productivity to increased meltwater discharge around Greenland. Nature Communications, 9(1), 3256. https://doi.org/ $10.1038 / \mathrm{s} 41467-018-05488-8$

Hughes Clarke, J. E. (2016). First wide-angle view of channelized turbidity currents links migrating cyclic steps to flow characteristics Nature Communications, 7(1), 11896. https://doi.org/10.1038/ncomms11896

Hughes Clarke, J. E., Muggah, J., Renoud, W., Bell, T., Forbes, D. L., Cowan, B., \& Kennedy, J. (2015). Reconnaissance seabed mapping around Hall and Cumberland Peninsulas, Nunavut: Opening up southeast Baffin Island to nearshore geological investigations. Summary of activities, 133-144.

Kostic, S., Casalbore, D., Chiocci, F., Lang, J., \& Winsemann, J. (2019). Role of upper-flow regime bedforms emplaced by sediment gravity flows in the evolution of deltas. Journal of Marine Science and Engineering, 7(1). https://doi.org/10.3390/jmse7010005

Kostic, S., Sequeiros, O., Spinewine, B., \& Parker, G. (2010). Cyclic steps: A phenomenon of supercritical shallow flow from the high mountains to the bottom of the ocean. Journal of Hydro-Environment Research, 3(4), 167-172. https://doi.org/10.1016/j.jher.2009.10.002

Lantuit, H., \& Pollard, W. H. (2008). Fifty years of coastal erosion and retrogressive thaw slump activity on Herschel Island, southern Beaufort Sea, Yukon Territory, Canada. Geomorphology, 95(1-2), 84-102. https://doi.org/10.1016/j.geomorph.2006.07.040

Lenaerts, J. T., van Angelen, J. H., van den Broeke, M. R., Gardner, A. S., Wouters, B., \& van Meijgaard, E. (2013). Irreversible mass loss of Canadian Arctic Archipelago glaciers. Geophysical Research Letters, 40, 870-874. https://doi.org/10.1002/grl.50214

Lonne, I., \& Nemec, W. (2004). High-arctic fan delta recording deglaciation and environment disequilibrium. Sedimentology, 51(3), 553-589. https://doi.org/10.1111/j.1365-3091.2004.00636.x

Messager, M. L., Lehner, B., Grill, G., Nedeva, I., \& Schmitt, O. (2016). Estimating the volume and age of water stored in global lakes using a geo-statistical approach. Nature Communications, 7(1), 13603. https://doi.org/10.1038/ncomms13603

Normandeau, A., Dietrich, P., Lajeunesse, P., St-Onge, G., Ghienne, J.-F., Duchesne, M. J., \& Francus, P. (2017). Timing and controls on the delivery of coarse sediment to deltas and submarine fans on a formerly glaciated coast and shelf. GSA Bulletin, 129, 1424-1441.

Normandeau, A., Lajeunesse, P., Poiré, A. G., \& Francus, P. (2016). Morphological expression of bedforms formed by supercritical sediment density flows on four fjord-lake deltas of the south-eastern Canadian Shield (Eastern Canada). Sedimentology, 63(7), 2106-2129. https:// doi.org/10.1111/sed.12298

Normandeau, A., Lajeunesse, P., St-Onge, G., Bourgault, D., Drouin, S. S. O., Senneville, S., \& Bélanger, S. (2014). Morphodynamics in sediment-starved inner-shelf submarine canyons (Lower St. Lawrence Estuary, Eastern Canada). Marine Geology, 357, 243-255. https:// doi.org/10.1016/j.margeo.2014.08.012

Overeem, I., Anderson, R. S., Wobus, C. W., Clow, G. D., Urban, F. E., \& Matell, N. (2011). Sea ice loss enhances wave action at the Arctic coast. Geophysical Research Letters, 38, L17503. https://doi.org/10.1029/2011GL048681

Overeem, I., Hudson, B. D., Syvitski, J. P., Mikkelsen, A. B., Hasholt, B., van den Broeke, M. R., et al. (2017). Substantial export of suspended sediment to the global oceans from glacial erosion in Greenland. Nature Geoscience, 10(11), ngeo3046), 859-863. https://doi.org/10.1038/ ngeo3046

Perner, K., Leipe, T., Dellwig, O., Kuijpers, A., Mikkelsen, N., Andersen, T. J., \& Harff, J. (2010). Contamination of arctic fjord sediments by $\mathrm{Pb}-\mathrm{Zn}$ mining at Maarmorilik in central West Greenland. Marine Pollution Bulletin, 60(7), 1065-1073. https://doi.org/10.1016/j. marpolbul.2010.01.019

Pfeffer, W. T., Arendt, A. A., Bliss, A., Bolch, T., Cogley, J. G., Gardner, A. S., et al., \& The Randolph Consortium (2014). The Randolph Glacier Inventory: A globally complete inventory of glaciers. Journal of Glaciology, 60(221), 537-552. https://doi.org/10.3189/ 2014JoG13J176

Pope, E. L., Normandeau, A., O'Cofaigh, C., Stokes, C. R., \& Talling, P. (2019). Controls on the formation of turbidity current channels associated with marine-terminating glaciers and ice sheets. Marine Geology. https://doi.org/10.1016/j.margeo.2019.05.010

Serreze, M. C., Holland, M. M., \& Stroeve, J. (2007). Perspectives on the Arctic's shrinking sea-ice cover. Science, 315(5818), $1533-1536$. https://doi.org/10.1126/science.1139426

Smith, D. P., Ruiz, G., Kvitek, R., \& Iampietro, P. J. (2005). Semiannual patterns of erosion and deposition in upper Monterey Canyon from serial multibeam bathymetry. GSA Bulletin, 117(9), 1123-1133. https://doi.org/10.1130/B25510.1

Smith, R. W., Bianchi, T. S., Allison, M., Savage, C., \& Galy, V. (2015). High rates of organic carbon burial in fjord sediments globally. Nature Geoscience, 8(6), ngeo2421), 450-453. https://doi.org/10.1038/ngeo2421

Strahler, A. N. (1957). Quantitative analysis of watershed geomorphology. Eos. Transactions of the American Geophysical Union, 38(6), 913-920. https://doi.org/10.1029/TR038i006p00913 
Syvitski, J. P. (1989). On the deposition of sediment within glacier-influenced fjords: oceanographic controls. Marine Geology, 85(2-4), 301-329. https://doi.org/10.1016/0025-3227(89)90158-8

Syvitski, J. P., Farrow, G. E., Atkinson, R. J. A., Moore, P. G., \& Andrews, J. T. (1989). Baffin Island fjord macrobenthos: Bottom communities and environmental significance. Arctic, 42(3), 232-247. https://doi.org/10.14430/arctic1662

Van Wychen, W., Copland, L., Burgess, D. O., Gray, L., \& Schaffer, N. (2015). Glacier velocities and dynamic discharge from the ice masses of Baffin Island and Bylot Island, Nunavut, Canada. Canadian Journal of Earth Sciences, 52(11), 980-989. https://doi.org/10.1139/cjes2015-0087

Velicogna, I. (2009). Increasing rates of ice mass loss from the Greenland and Antarctic ice sheets revealed by GRACE. Geophysical Research Letters, 36, L19503. https://doi.org/10.1029/2009GL040222

Winsemann, J., Lang, J., Polom, U., Loewer, M., Igel, J., Pollok, L., \& Brandes, C. (2018). Ice-marginal forced regressive deltas in glacial lake basins: Geomorphology, facies variability and large-scale depositional architecture. Boreas, 47(4), 973-1002. https://doi.org/10.1111/ bor.12317

Zwally, H. J., Li, J., Brenner, A. C., Beckley, M., Cornejo, H. G., DiMarzio, J., et al. (2011). Greenland ice sheet mass balance: distribution of increased mass loss with climate warming; 2003-07 versus 1992-2002. Journal of Glaciology, 57(201), 88-102. https://doi.org/10.3189/ 002214311795306682 